\title{
Decontamination of Arsenic in Actual Water Samples by Calcium Containing Layered Double Hydroxides from a Convenient Synthesis Method
}

\author{
Hongtao Lu ${ }^{1,2}$, Shuxia Liu ${ }^{1}$, Hua Zhang ${ }^{1}$, Yanling Qiu ${ }^{3}$, Jianfu Zhao ${ }^{1}$ and Zhiliang Zhu ${ }^{1, *}$ \\ 1 State Key Laboratory of Pollution Control and Resource Reuse, Tongji University, Shanghai 200092, China; \\ 2013luhongtao@tongji.edu.cn (H.L.); 1333412@tongji.edu.cn (S.L.); zhhua@tongji.edu.cn (H.Z.); \\ zhaojianfu@tongji.edu.cn (J.Z.) \\ 2 Post Doctoral Research Station, College of Civil Engineering, Tongji University, Shanghai 200092, China \\ 3 Key Laboratory of Yangtze River Water Environment, Ministry of Education, Tongji University, \\ Shanghai 200092, China; ylqiu@tongji.edu.cn \\ * Correspondence: zzl@tongji.edu.cn; Tel.: +86-21-6598-2426
}

Received: 25 July 2018; Accepted: 23 August 2018; Published: 28 August 2018

\begin{abstract}
A series of calcium-containing layered double hydroxides (LDHs) and calcined product (CLDH) were synthesized using a comparative simple synthesis method (without using organic solvents and with a shortened reaction time) and applied in the adsorption of arsenic in water. The adsorption performance of arsenate on these LDHs and CLDH were studied using batch tests. The effects of various factors during the adsorption process, such as $\mathrm{pH}$ of the solution, dosage of materials, coexisting ions, contact time, and initial arsenate concentration, were evaluated. The maximum adsorption capacity of arsenate on three materials (CaFe-CLDH, CaFe-Cl-LDH, $\mathrm{CaFe}-\mathrm{NO}_{3}-\mathrm{LDH}$ ) were $156.0 \mathrm{mg} \cdot \mathrm{g}^{-1}, 150.5 \mathrm{mg} \cdot \mathrm{g}^{-1}$, and $148.0 \mathrm{mg} \cdot \mathrm{g}^{-1}$, respectively. When the concentration of $\mathrm{CaFe}-\mathrm{CLDH}$ was $0.5 \mathrm{~g} \cdot \mathrm{L}^{-1}$, the concentration of arsenate was reduced from $5000 \mu \mathrm{g} \cdot \mathrm{L}^{-1}$ to $10 \mu \mathrm{g} \cdot \mathrm{L}^{-1}$ after adsorption. Moreover, when the $\mathrm{CaFe}-\mathrm{NO}_{3}-\mathrm{LDH}$ or $\mathrm{CaFe}-\mathrm{Cl}-\mathrm{LDH}$ dosage was $1.0 \mathrm{~g} \cdot \mathrm{L}^{-1}$, a similar decontamination result could be achieved. The synthesized CaFe-CLDH was used to treat actual contaminated water samples from a river in a mining area north of Lengshuijiang City in Hunan Province, China. After treating using CaFe-CLDH, the residual arsenic concentration of actual water samples can fully meet the requirements for arsenic in the drinking water standards of the World Health Organization and China. This indicates that synthetic CaFe-CLDH has the potential to serve as an effective adsorbent for the removal of arsenic contamination.
\end{abstract}

Keywords: calcium; layered double hydroxides; arsenic; adsorption; actual water sample

\section{Introduction}

Arsenic pollution in water has always been a concern [1]. In many countries and regions, there are arsenic pollution problems in water environments. The concentration of arsenic in polluted areas is generally higher than $50 \mu \mathrm{g} \cdot \mathrm{L}^{-1}$, and in some areas the concentration of arsenic in water is above $1000 \mu \mathrm{g} \cdot \mathrm{L}^{-1}$ [2-6]. A variety of arsenic pollution control methods have been developed, such as filtration $[7,8]$, phytoremediation $[9,10]$, coagulation [11-13], membrane [14,15], ion exchange [16,17], and adsorption [18-20].One of the most convenient methods to apply is adsorption [21,22].

Layered double hydroxides (LDHs) have a layered structure of anionic clay. The general formula is $\left[\mathrm{M}^{\mathrm{II}}{ }_{1-\mathrm{x}} \mathrm{M}^{\mathrm{III}}{ }_{\mathrm{x}}(\mathrm{OH})_{2}\right]^{\mathrm{x}+}\left(\mathrm{A}^{\mathrm{n}-}\right)_{\mathrm{x} / \mathrm{n}} \cdot \mathrm{mH}_{2} \mathrm{O}$, where $\mathrm{M}^{\mathrm{II}}$ and $\mathrm{M}^{\mathrm{III}}$ are divalent and trivalent cations, respectively, and $\mathrm{A}^{\mathrm{n}-}$ denotes the interlayer anion [23,24]. LDHs have been widely used for pollutant removal in water. They may be the most suitable adsorbents for the treatment of arsenic because the 
LDHs synthesis process is relatively simple and cost effective. In recent years, many studies have focused on the synthesis of LDHs materials and used them for the purification of arsenic-polluted water $[25,26]$. However, in the process of using LDHs for the treatment of arsenic contamination in water, some of the harmful heavy metals in the material may dissolve (such as copper, manganese, aluminum, etc.); this may cause new contamination [27]. LDHs containing calcium and iron may be a better choice for removing arsenic from water. Some researchers have synthesized CaFe-LDHs, but the synthesis takes a long time, and the process uses ethanol, which is not a green synthetic method [28]. There are also complicated methods, such as using hot sodium hydroxide solution or grinding calcium hydroxide during synthesis $[29,30]$. Thus far, to the best of our knowledge, CaFe-LDHs materials have not been used to adsorb arsenic in water and to treat actual water samples.

In this study, we focused on the synthesis of CaFe-LDHs using convenient synthesis methods (without using organic solvents and shortening the reaction time) and used them for the treatment of arsenate pollution in actual water samples from a river. The adsorption of arsenate on a series of CaFe-LDHs was studied using batch adsorption tests. The effects on the adsorption by various factors, including initial $\mathrm{pH}$ of the solution, dosage of material, coexisting ions, contact time, and initial pollutants concentration, were evaluated. The synthesized materials have been used to treat actual contaminated water samples from a river in a mining area north of Lengshuijiang City in Hunan Province, China. The possible mechanisms of adsorption are also discussed.

\section{Materials and Methods}

\subsection{Chemicals}

The chemicals used in the synthesis experiments were of analytical grade and purchased from Sinopharm Group Reagent Co., Ltd., Shanghai, China. Arsenate $\left(\mathrm{Na}_{2} \mathrm{HAsO}_{4} \cdot 7 \mathrm{H}_{2} \mathrm{O}\right)$ was purchased from Sigma Aldrich with a purity higher than $98 \%$. A stock solution of $1000 \mathrm{mg} \cdot \mathrm{L}^{-1}$ As (V) was prepared with Milli-Q water (18.2 $\mathrm{M} \Omega \mathrm{cm}$ at $298 \mathrm{~K})$. The working solutions were obtained by diluting the stock solutions with de-ionized water.

\subsection{Synthesis of Materials}

CaFe-LDHs were synthesized using a co-precipitation method [24,28,31]. First, 0.05 mol $\mathrm{Ca}\left(\mathrm{NO}_{3}\right)_{2} \cdot 4 \mathrm{H}_{2} \mathrm{O}$ and $0.025 \mathrm{~mol} \mathrm{Fe}\left(\mathrm{NO}_{3}\right)_{3} \cdot 9 \mathrm{H}_{2} \mathrm{O}$ were dissolved in $100 \mathrm{~mL}$ of Milli-Q water to obtain solution I. $0.1 \mathrm{~mol} \mathrm{NaNO}_{3}$ and $0.2 \mathrm{~mol}$ of $\mathrm{NaOH}$ was dissolved in $100 \mathrm{~mL}$ of Milli-Q water to obtain solution II. Then solution I and solution II were simultaneously dropped into stirred three-necked flasks containing $50 \mathrm{~mL}$ of Milli-Q water with nitrogen protection. The $\mathrm{pH}$ value was maintained around 13. After completion of the reaction, the mixture was stirred for $30 \mathrm{~min}$, then suspensions were placed in a 353-K oven and aged for $24 \mathrm{~h}$. Centrifugal separation and washing were carried out next. The precipitate was washed repeatedly with de-ionized water until the $\mathrm{pH}$ of the supernatant was neutral. The obtained material was then dried at $353 \mathrm{~K}$ and ground into a powder. The product was named $\mathrm{CaFe}-\mathrm{NO}_{3}-\mathrm{LDH}$.

$\mathrm{CaFe}-\mathrm{CO}_{3}-\mathrm{LDHwas}$ also prepared using the same method as above by using $\mathrm{Na}_{2} \mathrm{CO}_{3}$ instead of $\mathrm{NaNO}_{3}$. CaFe- $-\mathrm{CO}_{3}-\mathrm{LDH}$ were calcined at $773 \mathrm{~K}$ in a muffle furnace for $4 \mathrm{~h}$. After cooling, the product was obtained and named $\mathrm{CaFe}-\mathrm{CLDH}$.

$\mathrm{CaFe}-\mathrm{Cl}-\mathrm{LDH}$ was prepared using the same methodas $\mathrm{CaFe}-\mathrm{NO}_{3}-\mathrm{LDH}$ using the corresponding chloride $\left(\mathrm{CaCl}_{2} \cdot 2 \mathrm{H}_{2} \mathrm{O}, \mathrm{FeCl}_{3} \cdot 6 \mathrm{H}_{2} \mathrm{O}, \mathrm{NaCl}\right)$ instead of nitrate $\left(\mathrm{Ca}\left(\mathrm{NO}_{3}\right)_{2} \cdot 4 \mathrm{H}_{2} \mathrm{O}, \mathrm{Fe}\left(\mathrm{NO}_{3}\right)_{3} \cdot 9 \mathrm{H}_{2} \mathrm{O}, \mathrm{NaNO}_{3}\right)$.

\subsection{Characterization and Analysis}

The aqueous arsenate concentration was determined by an inductively coupled plasma emission spectrometer (ICP)—Agilent (ICP-720 ES, Agilent Technologies, Santa Clara, CA, USA)—and atomic fluorescence spectrometry (AFS)(FP6-A, PERSEE).The materials were characterized with CuK $\alpha$ radiation operated at a voltage of $40 \mathrm{kV}$, and a current of $40 \mathrm{~mA}$, using an X-ray diffractometer (D8 
Advance, Bruker, Beijing, China) [32,33] and a specific surface area analyzer (Autosorb-iQ, Quanta Chrome Instruments, Boynton Beach, FL, USA). The Fourier transfer infrared (FTIR) spectrum was recorded using an FTIR instrument (Nicolet 6700, Nicolet, Nicolet Madison, WI, USA) in the wave number range of $400-4000 \mathrm{~cm}^{-1}$. Samples were mixed with oven dried spectroscopic grade potassium bromide. The surface areas were calculated by the Brunauer-Emmett-Teller (BET) method, and the pore size distribution and total volume were determined by the Brunauer-Joyner-Hallenda (BJH) method, which was applied to the desorption data. Scanning electron microscopy was performed using a CM200FEG (PHILIPS) and S-4800 (HITACHI). The water samples from the river in the north mining area of Lengshuijiang City were analyzed using inductively coupled plasma mass (ICP-MS) (Agilent Technologies), ICP and AFS. ICP was used to accurately determine the concentration of arsenic and other metals in the water samples (concentration range: $0.05 \sim 100 \mathrm{mg} \cdot \mathrm{L}^{-1}$ ), while ICP-MS was used to accurately determine the concentration of arsenic and other metals in water samples (concentration range: $0.1 \sim 50 \mu \mathrm{g} \cdot \mathrm{L}^{-1}$ ). AFS was used to check whether the concentration of arsenic after adsorption is lower than the limit specified by the World Health Organization (WHO) drinking water standard (concentration range: $0 \sim 10 \mu \mathrm{g} \cdot \mathrm{L}^{-1}$ ) [34].

\subsection{Batch Adsorption Experiments}

Batch adsorption experiments were carried out using a conical flask as the adsorption reaction vessel and placed in a constant-temperature shaking incubator at $298 \mathrm{~K}$ with $150 \mathrm{rpm}$ [35]. After reaction, the supernatants were collected and filtered with an $0.22 \mu \mathrm{m}$ needle filter before analysis of the residual arsenate. All experiments were repeated twice. In the adsorption isothermal experiment, the initial $\mathrm{pH}$ values of working solutions were adjusted to 6.0 . The dosage of materials was $0.2 \mathrm{~g} \cdot \mathrm{L}^{-1}$. The concentration range of arsenate was from $1 \mathrm{mg} \cdot \mathrm{L}^{-1}$ to $100 \mathrm{mg} \cdot \mathrm{L}^{-1}$. The adsorption reaction lasted for $24 \mathrm{~h}$ to achieve equilibrium. The concentration of arsenic was $10 \mathrm{mg} \cdot \mathrm{L}^{-1}$, initial $\mathrm{pH}$ was adjusted to 6.0, and the dosage of materials was $0.2 \mathrm{~g} \cdot \mathrm{L}^{-1}$ in the test of adsorption kinetics [36]. In order to study the effects of coexisting ions on arsenic adsorption, the initial concentration of arsenate was set to5 $\mathrm{mg} \cdot \mathrm{L}^{-1}$ and a certain concentration of anionic sodium salt $\left(\mathrm{NaCl}, \mathrm{NaNO}_{3}, \mathrm{Na}_{2} \mathrm{CO}_{3}, \mathrm{Na}_{2} \mathrm{SO}_{4}\right.$, $\mathrm{Na}_{2} \mathrm{HPO}_{4}$ ) was added to the arsenate solution. The $\mathrm{pH}$ of the solution was 6.0 and the dosage of adsorbents was $0.2 \mathrm{~g} \cdot \mathrm{L}^{-1}$. The initial concentration was set for $5 \mathrm{mg} \cdot \mathrm{L}^{-1}$ in the experiments of dosage effect. The $\mathrm{pH}$ of the system was adjusted to 6.0. The dosage of adsorbents was set from $0.1 \mathrm{~g} \cdot \mathrm{L}^{-1}$ to $1.0 \mathrm{~g} \cdot \mathrm{L}^{-1}$. In the evaluation of $\mathrm{pH}$ effect on the adsorption of arsenic, the initial arsenic concentration was $5 \mathrm{mg} \cdot \mathrm{L}^{-1}$. The $\mathrm{pH}$ range was from 3 to 10 and the dosage was $0.2 \mathrm{~g} \cdot \mathrm{L}^{-1}$.

\section{Results and Discussion}

\subsection{Characterization}

\subsubsection{X-ray Diffraction (XRD)}

The XRD patterns of $\mathrm{CaFe}-\mathrm{NO}_{3}-\mathrm{LDH}, \mathrm{CaFe}-\mathrm{Cl}-\mathrm{LDH}$, and CaFe-CLDH are shown in Figure 1a. It can be seen from Figure $1 \mathrm{a}$ that $\mathrm{CaFe}-\mathrm{NO}_{3}-\mathrm{LDHand} \mathrm{CaFe}-\mathrm{Cl}-\mathrm{LDH}$ show a series of characteristic diffraction peaks: (003), (006), (030), (033). The $\mathrm{d}(003)$ of $\mathrm{CaFe}-\mathrm{NO}_{3}-\mathrm{LDH}$ was $0.7836 \mathrm{~nm}$ and $\mathrm{d}(003)$ of CaFe-Cl-LDH was $0.7677 \mathrm{~nm}$, which were consistent with other studies. CaFe-CLDH exhibited a standard broad peak, which is the characteristic peak of the CLDH oxide. 


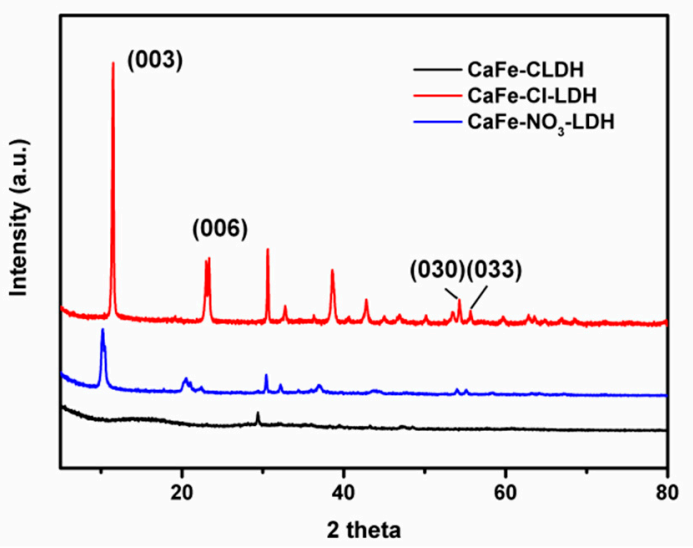

(a)

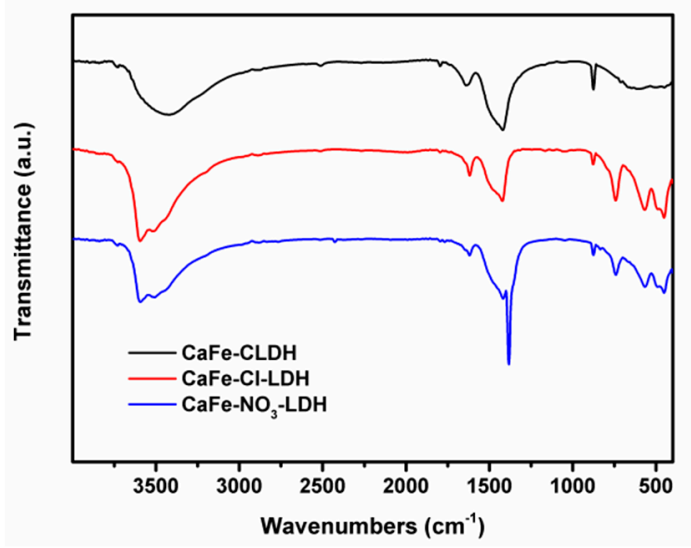

(b)

Figure 1. (a) XRD patterns of $\mathrm{CaFe}-\mathrm{NO}_{3}-\mathrm{LDH}, \mathrm{CaFe}-\mathrm{Cl}-\mathrm{LDH}$ and $\mathrm{CaFe}-\mathrm{CLDH}$. (b) Fourier Transfer Infrared (FTIR) spectra of $\mathrm{CaFe}_{-} \mathrm{NO}_{3}-\mathrm{LDH}, \mathrm{CaFe}-\mathrm{Cl}-\mathrm{LDH}$ and $\mathrm{CaFe}-\mathrm{CLDH}$.

\subsubsection{FTIR Analysis}

The infrared spectra of the synthesized materials are shown in Figure 1b. It can be seen from Figure $1 \mathrm{~b}$ that $\mathrm{CaFe}-\mathrm{NO}_{3}-\mathrm{LDH}$ and $\mathrm{CaFe}-\mathrm{Cl}-\mathrm{LDH}$ had the characteristic peaks of the infrared spectra of typical LDHs. The peaks appearing near $3600 \mathrm{~cm}^{-1}$ correspond to the hydrogen-oxygen bond stretching vibration peaks $\left(\mathrm{V}_{\mathrm{O}-\mathrm{H}}\right)$ of the lattice water molecules and -OH. Because of the adsorption of water on the surface of hydrotalcite, there was a certain amount of water molecules in the interlayer. Therefore, the bending vibration peak $\left(\delta_{\mathrm{H}-\mathrm{OH}}\right)$ of the crystal water appears at about $1600 \mathrm{~cm}^{-1}$. The peak around $1406 \mathrm{~cm}^{-1}$ of $\mathrm{CaFe}-\mathrm{NO}_{3}-\mathrm{LDH}$ was the peaks of $\mathrm{NO}_{3}{ }^{-}$[37]. The CaFe-Cl-LDH FTIR spectra showed the peak $\left(\mathrm{V}_{\mathrm{O}-\mathrm{H}}\right.$ at $\left.1486 \mathrm{~cm}^{-1}\right)$ and the peaks of metal oxygen bond and the metal hydrogen-oxygen bond $\left(\mathrm{V}_{\mathrm{M}-\mathrm{O}}\right.$ at $500 \mathrm{~cm}^{-1}$ to $1000 \mathrm{~cm}^{-1}$, where $\mathrm{M}$ is $\mathrm{Ca}$ or $\left.\mathrm{Fe}\right)[37,38]$.

\subsubsection{Analysis of Specific Surface Area and Pore Size Distribution}

The $\mathrm{N}_{2}$ adsorption/desorption isotherms of the materials are shown in Figure 2. It can be seen from Figure $2 \mathrm{a}-\mathrm{c}$ that the adsorption isotherm of the three materials basically conforms to the adsorption isotherm of class IV in the IUPAC classification. The hysteresis loop is basically consistent with the $\mathrm{H} 3$ hysteresis loop type and is characteristic of the flaky structure material [39]. In addition, there is no balance in the adsorption isotherm in the case of high relative pressure, indicating that the $\mathrm{N}_{2}$ adsorption process occurred in the pellet accumulation area. This also proved the material's layered structure. This is consistent with previous reports $[40,41]$. The surface area (multi-point BET method), total pore volume, and average pore size (the $\mathrm{BJH}$ method was used to calculate from desorption curve data) were calculated and the results are shown in Table 1. It can be seen that the specific surface area order is $\mathrm{CaFe}-\mathrm{NO}_{3}-\mathrm{LDH}>\mathrm{CaFe}-\mathrm{CLDH}>\mathrm{CaFe}-\mathrm{Cl}-\mathrm{LDH}$. The average pore diameters of materials are around $3 \mathrm{~nm}$. These data suggest that the three materials are mesoporous materials. 


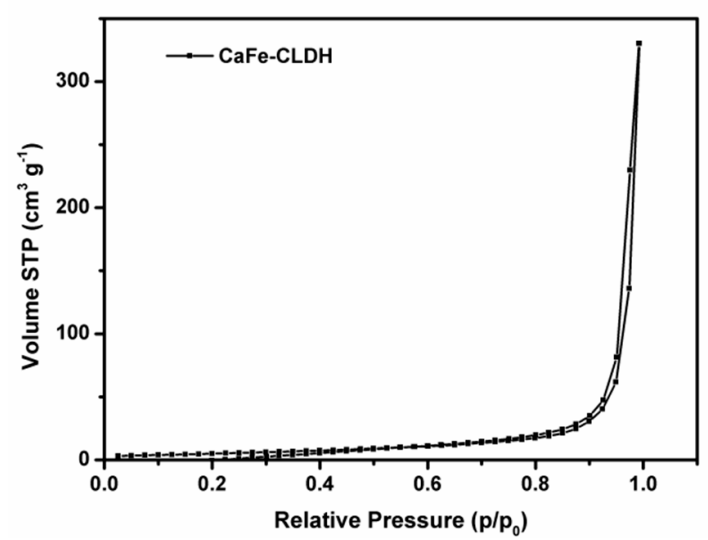

(a)

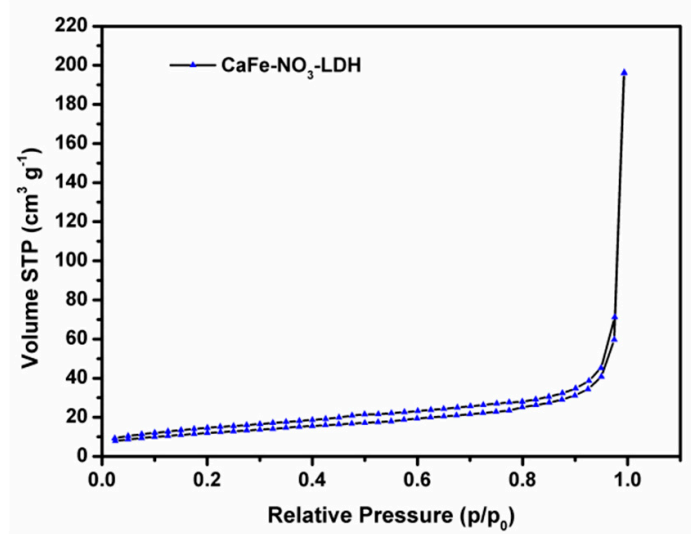

(c)

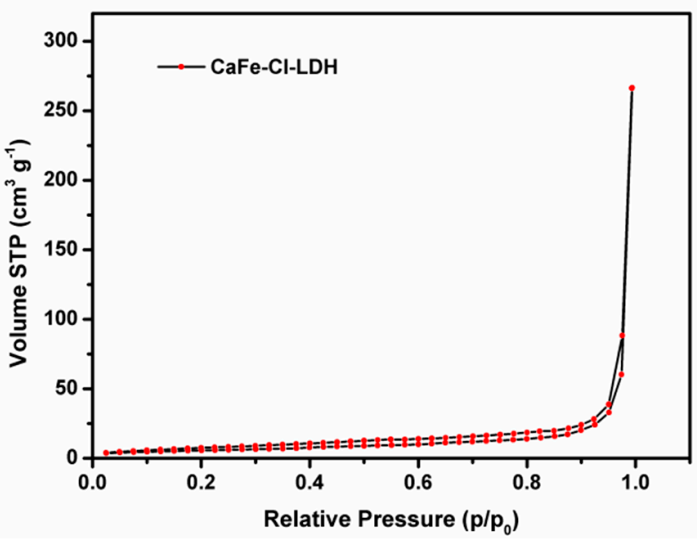

(b)

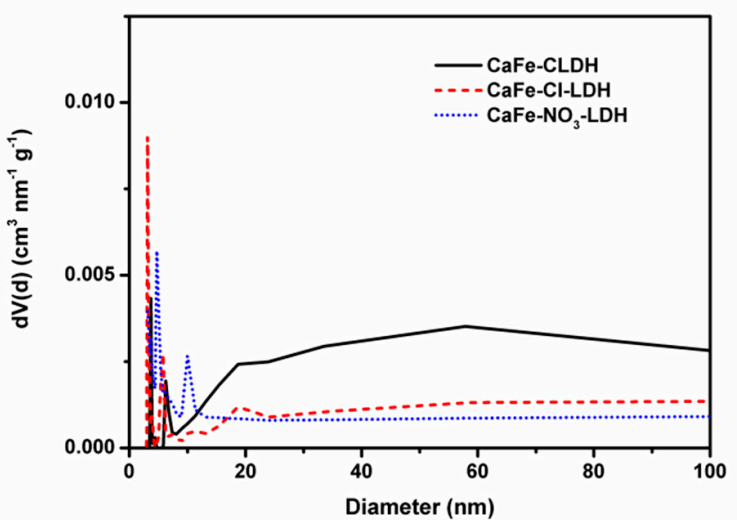

(d)

Figure 2. (a) $\mathrm{N}_{2}$ adsorption/desorption isotherms of CaFe-CLDH. (b) $\mathrm{N}_{2}$ adsorption/desorption

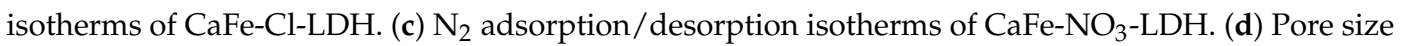
distribution of three materials (Brunauer-Joyner-Hallenda, BJHmethod).

Table 1. The specific surface area of the synthetic material, the average pore size, and the total pore volume.

\begin{tabular}{ccccc}
\hline Materials & $\begin{array}{c}\text { BET Surface } \\
\text { Area }\left(\mathbf{m}^{\mathbf{2}} \cdot \mathbf{g}^{\mathbf{- 1}}\right)\end{array}$ & $\begin{array}{c}\text { C-Value in } \\
\text { BET Equation }\end{array}$ & $\begin{array}{c}\text { Pore Volume } \\
\left(\mathbf{c m}^{\mathbf{3}} \cdot \mathbf{g}^{\mathbf{- 1}} \mathbf{)}\right.\end{array}$ & $\begin{array}{c}\text { Average Pore } \\
\text { Diameters (nm) }\end{array}$ \\
\hline $\mathrm{CaFe}-\mathrm{CLDH}$ & 21.17 & 18.14 & 0.5109 & 3.709 \\
$\mathrm{CaFe}-\mathrm{Cl}-\mathrm{LDH}$ & 20.68 & 70.74 & 0.4122 & 3.135 \\
$\mathrm{CaFe}-\mathrm{NO}_{3}-\mathrm{LDH}$ & 43.31 & 100.3 & 0.3037 & 2.359 \\
\hline
\end{tabular}

\subsubsection{Morphological Analysis}

The SEM images of CaFe-CLDH, CaFe-Cl-LDH, and CaFe- $\mathrm{NO}_{3}-\mathrm{LDH}$ materials are shown in Figure S1. It can be seen that $\mathrm{CaFe}-\mathrm{CLDH}, \mathrm{CaFe}-\mathrm{Cl}-\mathrm{LDH}$ and $\mathrm{CaFe}-\mathrm{NO}_{3}-\mathrm{LDH}$ all show a flaky morphology. This is also consistent with the results of the surface analysis of the materials; that is, the three synthesized materials have a sheet-like structure.

\subsection{Adsorption of Arsenic}

\subsubsection{Isotherms of Arsenic Adsorption}

In order to understand the adsorption process of arsenate on CaFe-LDHs and the related CLDHs, isothermal adsorption experiments were carried out. The Langmuir and Freundlich models were used 
to analyze the relative data obtained from the adsorption experiment for arsenate [42,43]. The fitting curves are 0 shown in Figure 3. The parameters of the curves were calculated, as shown in Table 2.

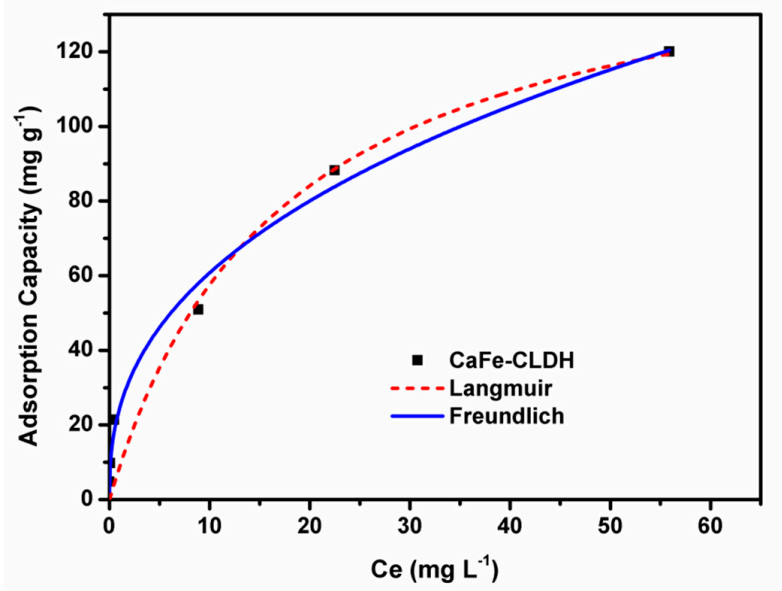

(a)

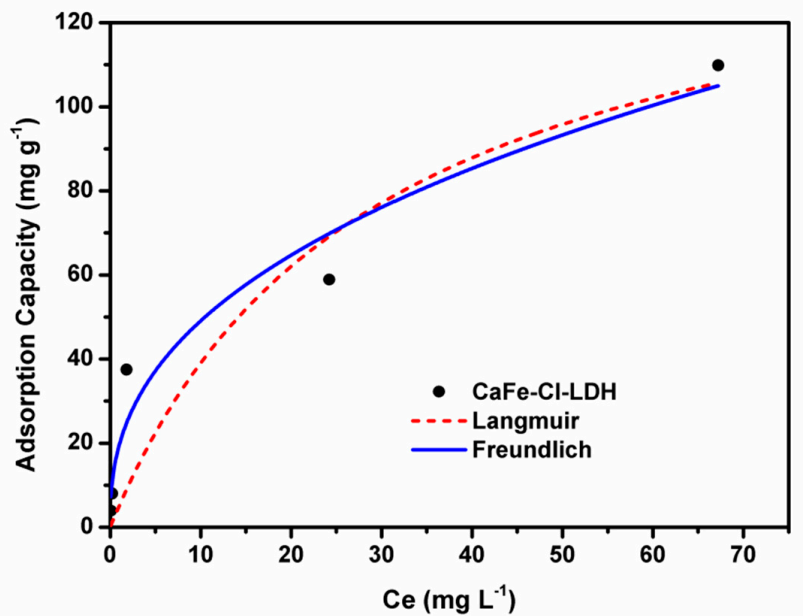

(b)

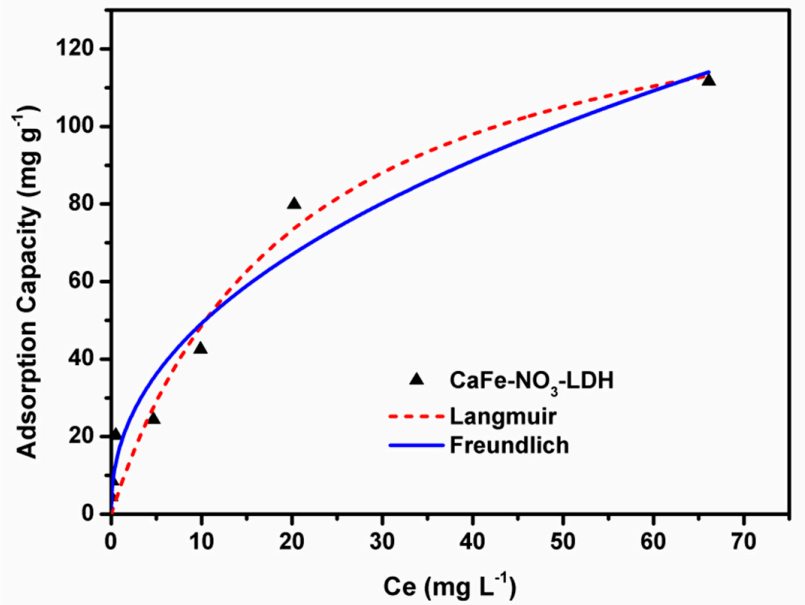

(c)

Figure 3. (a) Isothermal study of adsorption of arsenic with CaFe-CLDH. (b) Isothermal study of adsorption of arsenic with CaFe-Cl-LDH. (c) Isothermal study of adsorption of arsenic with $\mathrm{CaFe}-\mathrm{NO}_{3}-\mathrm{LDH}$ (Experimental condition: initial concentration range of arsenate was from $1 \mathrm{mg} \cdot \mathrm{L}^{-1}$ to $100 \mathrm{mg} \cdot \mathrm{L}^{-1}$, materials dosage $=0.2 \mathrm{~g} \cdot \mathrm{L}^{-1}$, initial $\mathrm{pH}=6.0$ ). 
The Freundlich adsorption isotherm model is in the following form:

$$
Q_{e}=K_{F} C_{e}^{\frac{1}{n}}
$$

where $Q_{e}\left(\mathrm{mg} \cdot \mathrm{g}^{-1}\right)$ is the equilibrium adsorption capacity, $K_{F}\left(\mathrm{~L} \cdot \mathrm{mg}^{-1}\right)$ is the Freundlich constant, and $1 / n$ is the heterogeneity factor.

The Langmuir model:

$$
Q_{e}=\frac{Q_{m} K_{L} C_{e}}{1+K_{L} C_{e}}
$$

where $C_{e}\left(\mathrm{mg} \cdot \mathrm{L}^{-1}\right)$ is the equilibrium concentration, $Q_{m}\left(\mathrm{mg} \cdot \mathrm{g}^{-1}\right)$ is the maximum and equilibrium adsorption capacity, and $K_{L}\left(\mathrm{~L} \cdot \mathrm{mg}^{-1}\right)$ is the Langmuir adsorption constant.

The adsorptions of arsenate on the three materials were more consistent with the Freundlich adsorption isotherm equation than the Langmuir model. The Freundlich isotherm model is based on multi-layer adsorption of adsorbate on a multiphase surface and is suitable for adsorption data within a limited concentration range [44].

\begin{tabular}{|c|c|c|c|c|c|c|}
\hline \multirow{2}{*}{ Materials } & \multicolumn{3}{|c|}{ Langmuir } & \multicolumn{3}{|c|}{ Freundlich } \\
\hline & $Q_{m}\left(\mathrm{mg} \cdot \mathrm{g}^{-1}\right)$ & $K_{L}\left(\mathrm{~L} \cdot \mathrm{mg}^{-1}\right)$ & $\mathbf{R}^{2}$ & $K_{F}\left(\mathrm{mg} \cdot \mathrm{g}^{-1}\right)\left(\mathrm{L} \cdot \mathrm{mg}^{-1}\right)^{-1 / n}$ & $n$ & $\mathbf{R}^{2}$ \\
\hline $\mathrm{CaFe}-\mathrm{CLDH}$ & 156.0 & 0.05848 & 0.9626 & 24.31 & 2.514 & 0.9920 \\
\hline CaFe-Cl-LDH & 150.5 & 0.03509 & 0.8241 & 19.57 & 2.504 & 0.9424 \\
\hline $\mathrm{CaFe}-\mathrm{NO}_{3}-\mathrm{LDH}$ & 148.0 & 0.04894 & 0.9448 & 17.64 & 2.245 & 0.9524 \\
\hline
\end{tabular}

Table 2. Fitting curve parameters of arsenate adsorption isothermal equation.

The comparison results of the maximum adsorption capacities of various adsorbents for arsenate adsorption are shown in Table 3. It was found that CaFe-LDHs in this study have a high adsorption capacity for arsenate, which makes them possible efficient adsorbents for arsenate removal from aqueous solutions.

\begin{tabular}{|c|c|c|c|c|}
\hline Adsorbents & $\begin{array}{c}\text { Concentration } \\
\text { Range }\left(\mathrm{mg} \cdot \mathrm{L}^{-1}\right)\end{array}$ & $\mathrm{pH}$ & $\begin{array}{c}\text { Adsorption } \\
\text { Capacity }\left(\mathrm{mg} \cdot \mathrm{g}^{-1}\right)\end{array}$ & Reference \\
\hline Leonardite char & $1-80$ & 7.0 & 8.4 & [45] \\
\hline Pyrite Ash & $0.01-0.5$ & 7.0 & 0.295 & [46] \\
\hline UltraCarb & $20-22$ & 6.0 & 51.3 & [47] \\
\hline $\mathrm{CeO}_{2}-\mathrm{ZrO}_{2}$ nanospheres & $0.5-60$ & 6.9 & 145.35 & [48] \\
\hline $\mathrm{Mg}-\mathrm{Fe}-\mathrm{Cl}-\mathrm{LDH}$ & $3.75-562.5$ & 6.0 & 129.5 & [49] \\
\hline $\mathrm{Zn}-\mathrm{Al}-\mathrm{SO}_{4}-\mathrm{LDH}$ & 900 & 9.0 & 74.9 & [50] \\
\hline $\mathrm{CaFe}-\mathrm{CLDH}$ & $1-100$ & 6.0 & 156.0 & This study \\
\hline $\mathrm{CaFe}-\mathrm{Cl}-\mathrm{LDH}$ & $1-100$ & 6.0 & 150.5 & This study \\
\hline $\mathrm{CaFe}-\mathrm{NO}_{3}-\mathrm{LDH}$ & $1-100$ & 6.0 & 148.0 & This study \\
\hline
\end{tabular}

Table 3. Comparison of adsorption capacity for arsenate onto CaFe-LDHs with other reported adsorbents.

\subsubsection{Kinetics of Arsenic Adsorption}

In order to study the kinetic process of the adsorption of arsenate by CaFe-CLDH, CaFe-Cl-LDH, and $\mathrm{CaFe}-\mathrm{NO}_{3}-\mathrm{LDH}$, the adsorption capacity variations with time were investigated. The pseudo-first order kinetic model and pseudo-second order kinetic model were used to fit the relevant data of the arsenate adsorption kinetics experiment [51]. The pseudo-first order kinetic model equation follows:

$$
\ln \left(Q_{e}-Q_{t}\right)=\ln Q_{e}-K_{1} t
$$


The pseudo-second order kinetic model equation follows:

$$
\frac{t}{Q_{t}}=\frac{1}{K_{2} Q_{e}{ }^{2}}+\frac{t}{Q_{e}}
$$

$Q_{e}\left(\mathrm{mg} \cdot \mathrm{g}^{-1}\right)$ and $Q_{t}\left(\mathrm{mg} \cdot \mathrm{g}^{-1}\right)$ are the adsorption amounts of the adsorbents at equilibrium and at time $t$ respectively; $K_{1}\left(\mathrm{~min}^{-1}\right)$ and $K_{2}\left[\mathrm{~g} \cdot(\mathrm{mg} \cdot \mathrm{min})^{-1}\right]$ are the adsorption rate constants. The resulting fitting curves are shown in Figure 4 , and the obtained fitting parameters are shown in Table 4.

As shown in Figure 4, the time required for arsenic to adsorb to equilibrium in material $\mathrm{CaFe}-\mathrm{NO}_{3}-\mathrm{LDH}$ was the shortest, followed by $\mathrm{CaFe}-\mathrm{Cl}-\mathrm{LDH}$, and arsenic took the longest time to adsorb to equilibrium with $\mathrm{CaFe}-\mathrm{CLDH}$. The reason may be that the $\mathrm{CaFe}-\mathrm{CLDH}$ adsorbs arsenate and undergoes structural remodeling that requires a longer equilibrium time.

As shown in Table 4, the correlation coefficients of the three materials with the pseudo-second order kinetic equation model are larger than those of the pseudo-first order kinetic equation. This suggests that the pseudo-second order kinetic model can better reflect the adsorption process of arsenate on the three materials. The correlation coefficients of the three materials using the pseudo-second order kinetic equation model were larger than those obtained by fitting the pseudo-first order kinetic equation. This indicates that the pseudo-second order kinetic equation model can better reflect the dynamic adsorption of arsenate by the three materials. This is also consistent with the conclusions obtained from many previous studies: the adsorption of arsenic by solid materials generally conforms to pseudo-secondary kinetics [35,52]. It could indicate that the process controlling the rate may be a chemical sorption involving LDHs and arsenate [53,54]. In addition, the adsorption rate constants $\mathrm{K}_{2}$ of $\mathrm{CaFe}_{-} \mathrm{NO}_{3}-\mathrm{LDH}$ were larger than that of $\mathrm{CaFe}-\mathrm{CLDH}$ and $\mathrm{CaFe}-\mathrm{Cl}-\mathrm{LDH}$ also indicating that the adsorption of arsenate in $\mathrm{CaFe}-\mathrm{NO}_{3}-\mathrm{LDH}$ was faster.

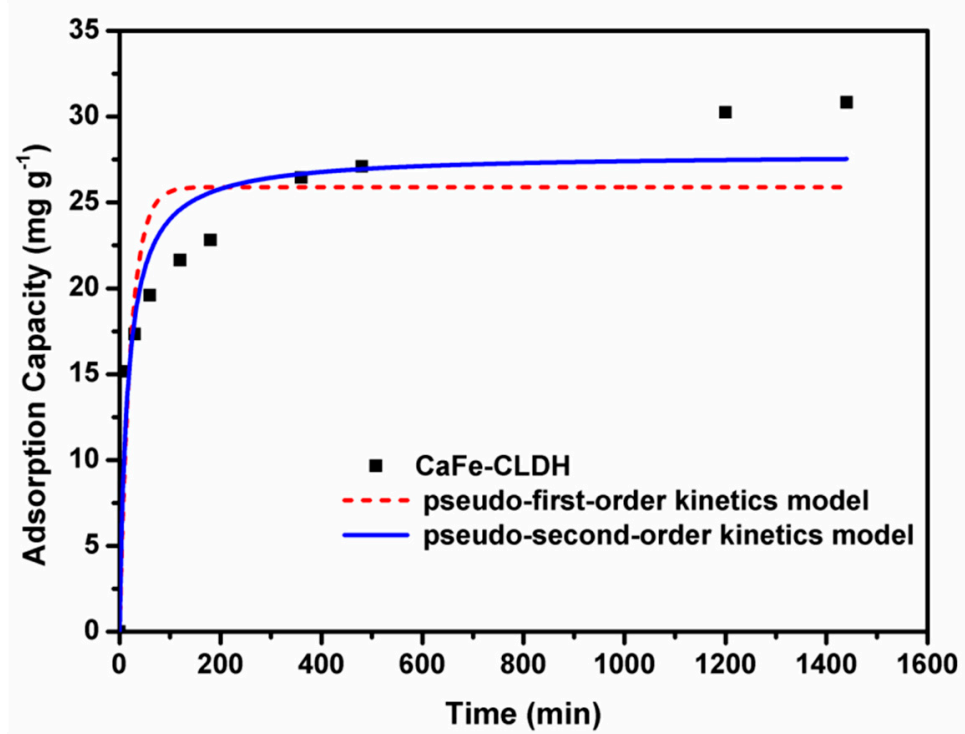

(a)

Figure 4. Cont. 


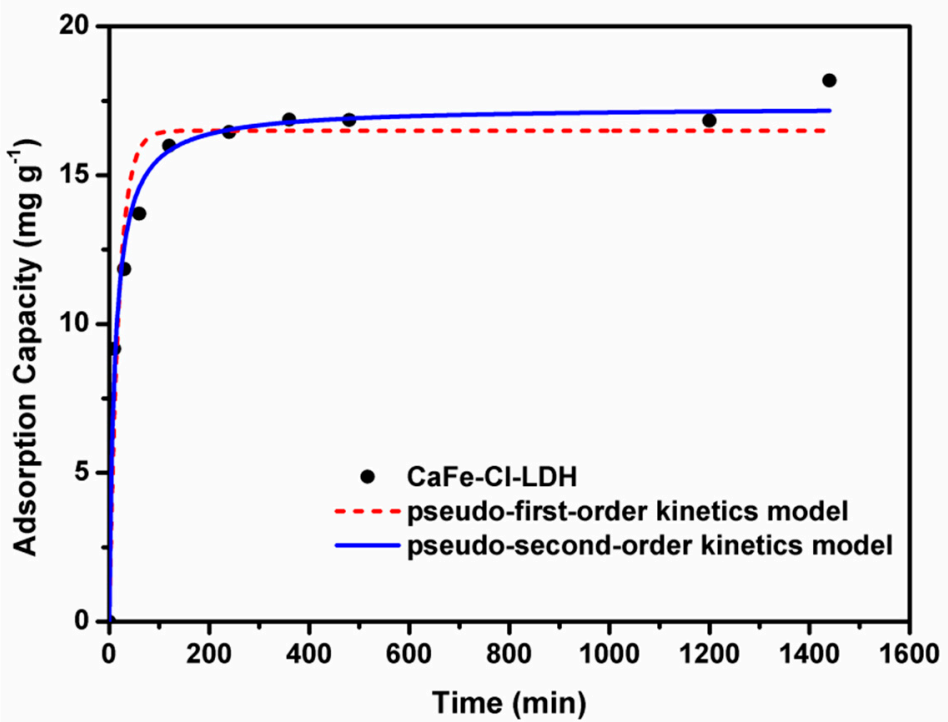

(b)

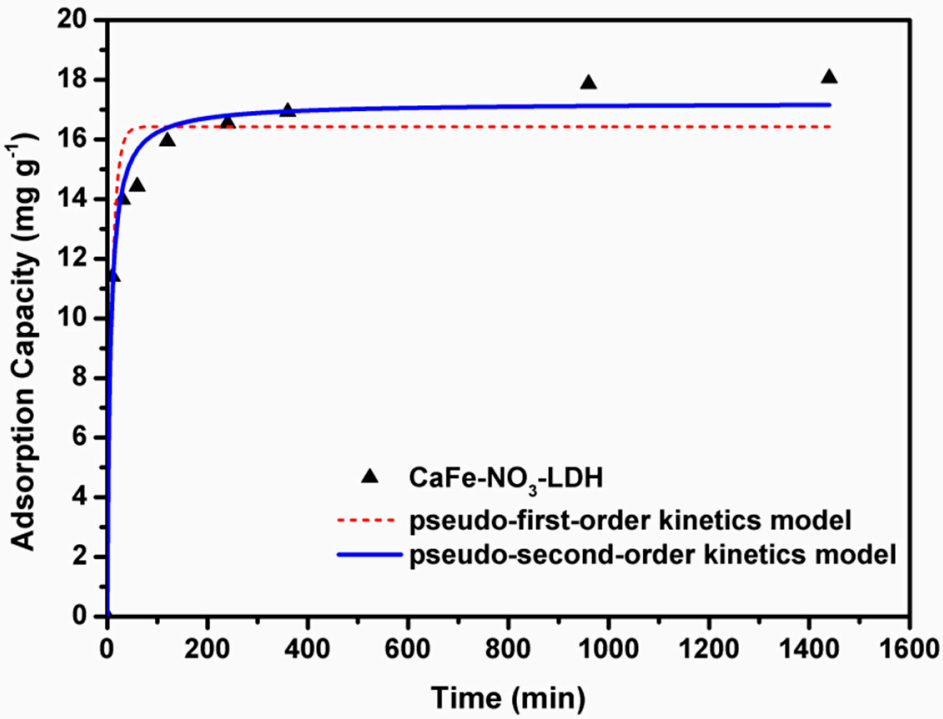

(c)

Figure 4. Kinetic fitting curve of arsenic adsorption on the three materials: (a) CaFe-CLDH; (b) $\mathrm{CaFe}-\mathrm{Cl}-\mathrm{LDH}$; (c) $\mathrm{CaFe}-\mathrm{NO}_{3}-\mathrm{LDH}$ (Experimental condition: initial concentration of arsenate was $10 \mathrm{mg} \cdot \mathrm{L}^{-1}$, materials dosage $=0.2 \mathrm{~g} \cdot \mathrm{L}^{-1}$, initial $\mathrm{pH}=6.0$ ).

Table 4. Fitting curve parameters of arsenic adsorption kinetic equation.

\begin{tabular}{|c|c|c|c|c|c|c|}
\hline \multirow{2}{*}{ Materials } & \multicolumn{3}{|c|}{ Pseudo First-Order } & \multicolumn{3}{|c|}{ Pseudo Second-Order } \\
\hline & $Q_{e}\left(\mathrm{mg} \cdot \mathrm{g}^{-1}\right)$ & $K_{1}\left(\min ^{-1}\right)$ & $\mathbf{R}^{2}$ & $Q_{e}\left(\mathrm{mg} \cdot \mathrm{g}^{-1}\right)$ & $K_{2}\left(\mathrm{~g} \cdot \mathrm{mg}^{-1} \cdot \min ^{-1}\right)$ & $\mathbf{R}^{2}$ \\
\hline CaFe-CLDH & 25.89 & 0.0461 & 0.8044 & 27.84 & 0.00226 & 0.9077 \\
\hline $\mathrm{CaFe}-\mathrm{Cl}-\mathrm{LDH}$ & 16.50 & 0.0539 & 0.9378 & 17.30 & 0.00517 & 0.9856 \\
\hline $\mathrm{CaFe}-\mathrm{NO}_{3}-\mathrm{LDH}$ & 16.43 & 0.1054 & 0.9428 & 17.23 & 0.00948 & 0.9832 \\
\hline
\end{tabular}

\subsubsection{Effect of $\mathrm{pH}$ on Arsenic Adsorption}

The effects of initial solution $\mathrm{pH}$ on arsenate adsorption are shown in Figure 5a. It can be seen from Figure $5 \mathrm{a}$ that the effect of $\mathrm{pH}$ on the adsorption of arsenate by CaFe-CLDH was not significant in the initial $\mathrm{pH}$ range from 3 to 10 . With the increase in $\mathrm{pH}$, the adsorption capacity decreased. This is 
similar to the previously reported adsorption behavior of arsenate on ferrihydrite: As the $\mathrm{pH}$ increases, the adsorption capacity for arsenate decreases [55]. This may be related to the electrostatic repulsion of arsenate and the surface occupation of active sites on the materials.

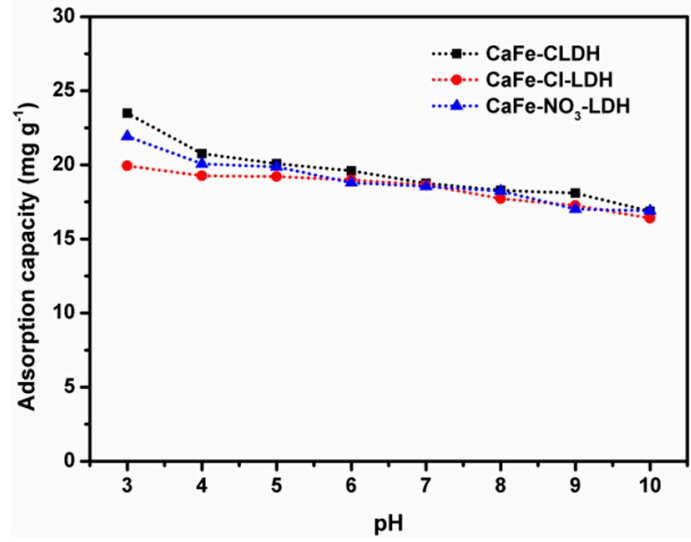

(a)

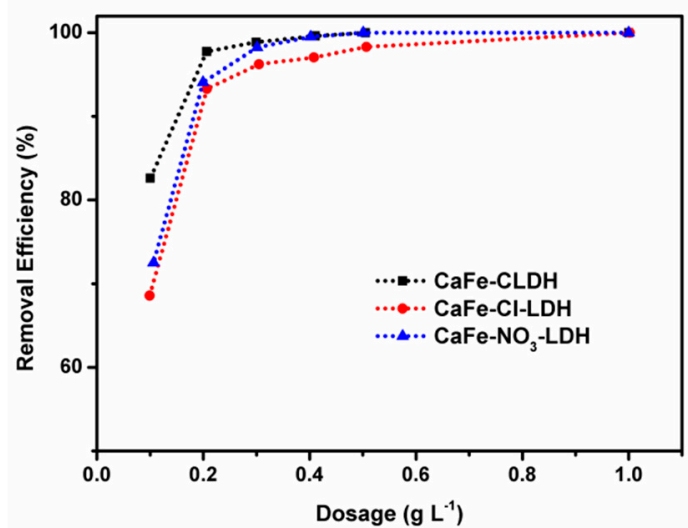

(b)

Figure 5. (a) Effect of $\mathrm{pH}$ on arsenic adsorption (Experimental condition: initial concentration of arsenate was $5 \mathrm{mg} \cdot \mathrm{L}^{-1}$, materials dosage $\left.=0.2 \mathrm{~g} \cdot \mathrm{L}^{-1}\right)$. (b) Effect of dosage on arsenic adsorption (Experimental condition: initial concentration of arsenate was $5 \mathrm{mg} \cdot \mathrm{L}^{-1}$, initial $\mathrm{pH}=6.0$ ).

\subsubsection{Effect of Materials Dosage on Arsenic Adsorption}

The effect of the adsorbent dosage on the removal efficiency of arsenic was evaluated by gradually increasing the dosage of the adsorbent in the experiment. The experimental results are shown in Figure 5b.

It can be seen from Figure $5 \mathrm{~b}$ that increasing the amount of adsorbent will increase the removal rate of arsenate. When the $\mathrm{CaFe}-\mathrm{NO}_{3}-\mathrm{LDH}$ or $\mathrm{CaFe}-\mathrm{Cl}-\mathrm{LDH}$ dosage was $1.0 \mathrm{~g} \cdot \mathrm{L}^{-1}$, the removal rate reached $99.9 \%$; the remaining arsenic concentration was below $10 \mu \mathrm{g} \cdot \mathrm{L}^{-1}$. Moreover, when the concentration of $\mathrm{CaFe}-\mathrm{CLDH}$ was $0.5 \mathrm{~g} \cdot \mathrm{L}^{-1}$, the same result could be achieved. The above situation can meet the concentration of arsenic limit requirements of the World Health Organization, EPA, and China's drinking water standards.

\subsubsection{Effects of Anions on Arsenic Adsorption}

The presence of various anions in the natural water may affect the adsorption of arsenate on the adsorbent, so several common anions in water were selected to study their effect on the adsorption of arsenic. The ions, including $\mathrm{PO}_{4}{ }^{3-}, \mathrm{SO}_{4}{ }^{2-}, \mathrm{CO}_{3}{ }^{2-}, \mathrm{NO}_{3}{ }^{-}$, and $\mathrm{Cl}^{-}$, were selected as the coexisting ions. The effects of excess anions on the adsorption of arsenate on materials were investigated. The experimental results were shown in Figure 6. The high concentration of $\mathrm{HPO}_{4}{ }^{2-}$ had a very significant inhibitory effect on the adsorption of arsenate, while the inhibitory effects of $\mathrm{SO}_{4}{ }^{2-}, \mathrm{Cl}^{-}$, and $\mathrm{NO}_{3}{ }^{-}$were not obvious. In general, the inhibitory effect of coexisting ions on arsenate adsorption was $\mathrm{HPO}_{4}{ }^{2-}>\mathrm{CO}_{3}{ }^{2-}>\mathrm{SO}_{4}{ }^{2-}>\mathrm{Cl}^{-}>\mathrm{NO}_{3}{ }^{-}$. 


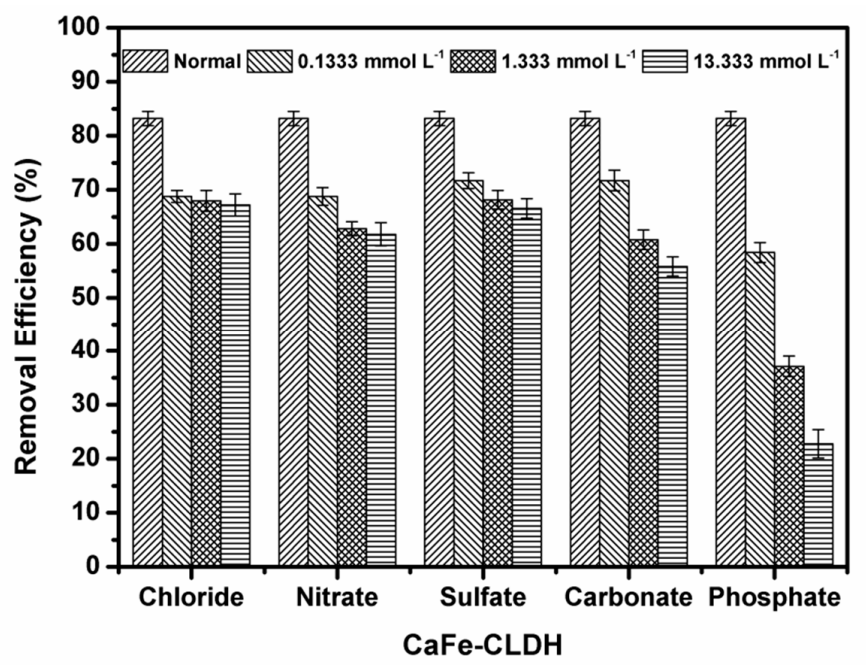

(a)

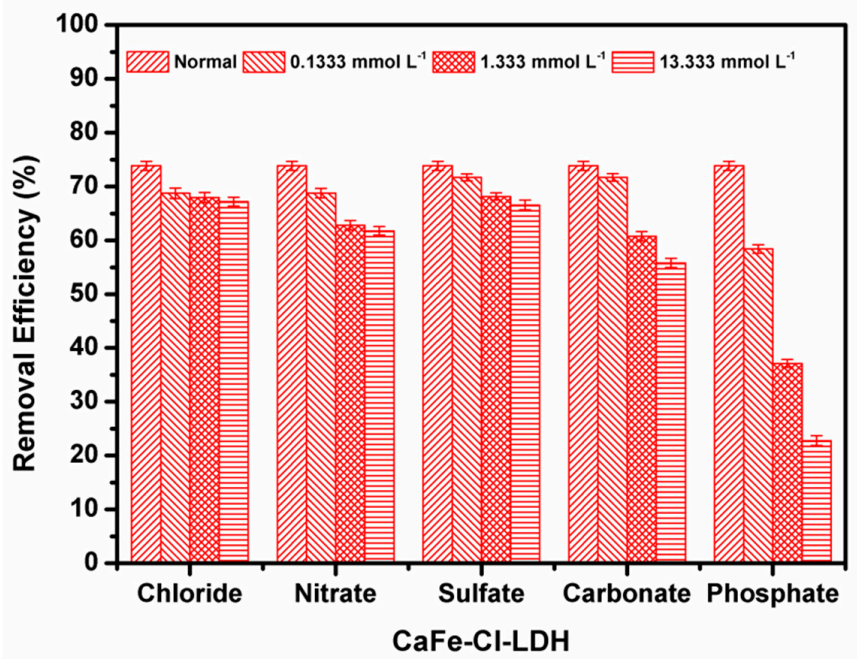

(b)

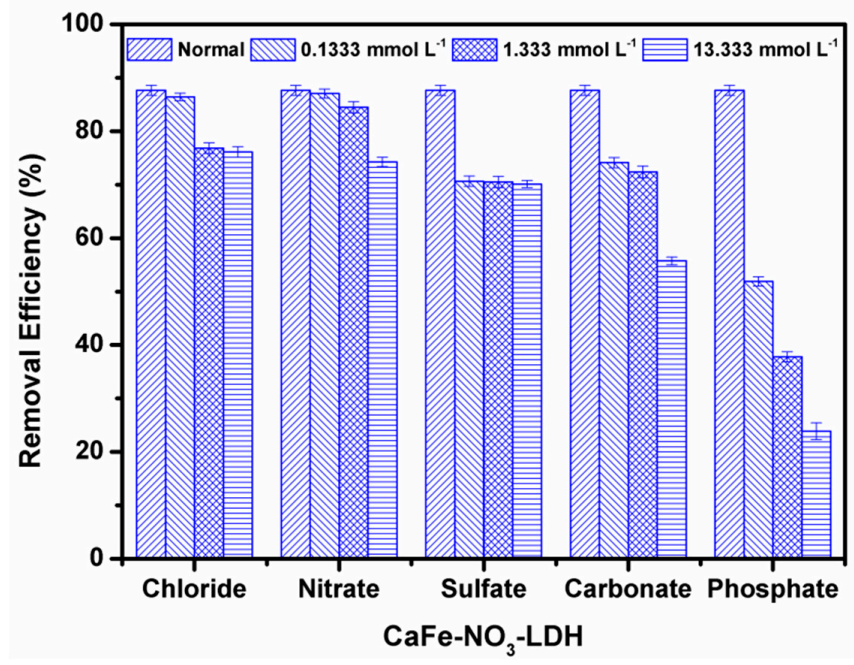

(c)

Figure 6. Effect of coexisting anions on arsenic removal by materials in water: (a) CaFe-CLDH; (b) CaFe-Cl-LDH; (c) $\mathrm{CaFe}_{-} \mathrm{NO}_{3}-\mathrm{LDH}$ (Experimental condition: initial concentration of arsenate was $5 \mathrm{mg} \cdot \mathrm{L}^{-1}$, materials dosage $=0.2 \mathrm{~g} \cdot \mathrm{L}^{-1}$, initial $\mathrm{pH}=6.0$ ). 


\subsubsection{Adsorption and Removal of Arsenic in Actual Water Samples}

The actual water samples were collected from the river of the North Mining Area, Lengshuijiang City in Hunan Province, China. The elemental analyses in actual water samples are shown in Table 5. The $\mathrm{pH}$ values of the water samples were 7.12 and 7.62, respectively. Arsenic in the water sample exists in the form of arsenate. The concentrations of arsenic were $0.03 \mathrm{mg} \cdot \mathrm{L}^{-1}$ and $1.11 \mathrm{mg} \cdot \mathrm{L}^{-1}$ respectively. The CaFe-CLDH was chosen as the adsorbent. After adsorption by $1 \mathrm{~g} \cdot \mathrm{L}^{-1} \mathrm{CaFe}-\mathrm{CLDH}$, the amount of the remaining arsenic concentration was $1.7 \mu \mathrm{g} \cdot \mathrm{L}^{-1}$ and $9.2 \mu \mathrm{g} \cdot \mathrm{L}^{-1}$, respectively. This is fully able to meet the requirements for the concentrations of arsenic in drinking water standards of the World Health Organization, EPA and China.

Table 5. Elemental analysis in actual water samples $\left(\mathrm{mg} \cdot \mathrm{L}^{-1}\right)$.

\begin{tabular}{cccccccccccc}
\hline Sample & As & Ba & Mg & Fe & Ca & K & Cu & Na & Al & P & Sb \\
\hline I & 0.03 & 0.03 & 9.24 & 0.54 & 6.89 & 1.9 & 0.01 & 10.62 & 0.47 & 0 & 0.18 \\
II & 1.11 & 0.04 & 7.69 & 0 & 6.64 & 9.8 & 0.01 & 36.09 & 0.21 & 0.02 & 0.1 \\
\hline
\end{tabular}

XRD of Ca-Fe-CLDH material after adsorption of As (V) is shown in Figure 7a. It can be found that the XRD pattern showed a series of characteristic diffraction peaks of LDHs. This is similar to the characterization result of arsenic adsorption onto LDHs calcined products in previous reports [56,57]. The SEM image in Figure $7 \mathrm{~b}$ also shows the significant appearance of the lamellar structure of LDHs. This indicated that the structure of LDHs had been rebuilt after adsorption.

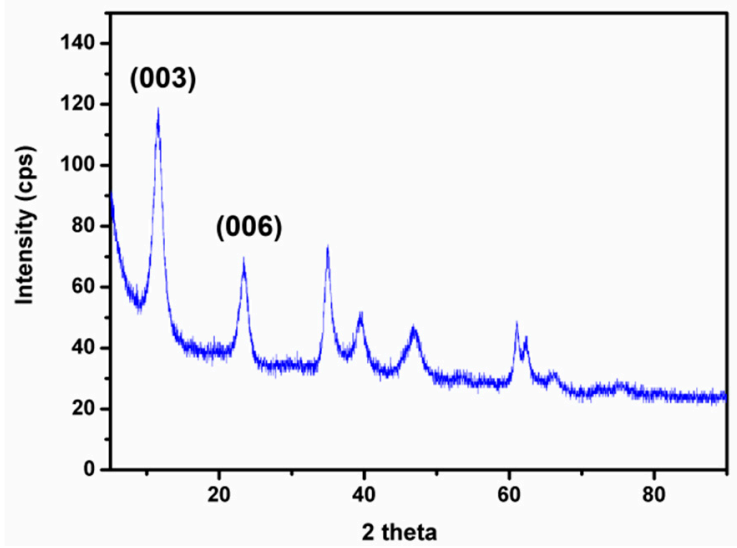

(a)

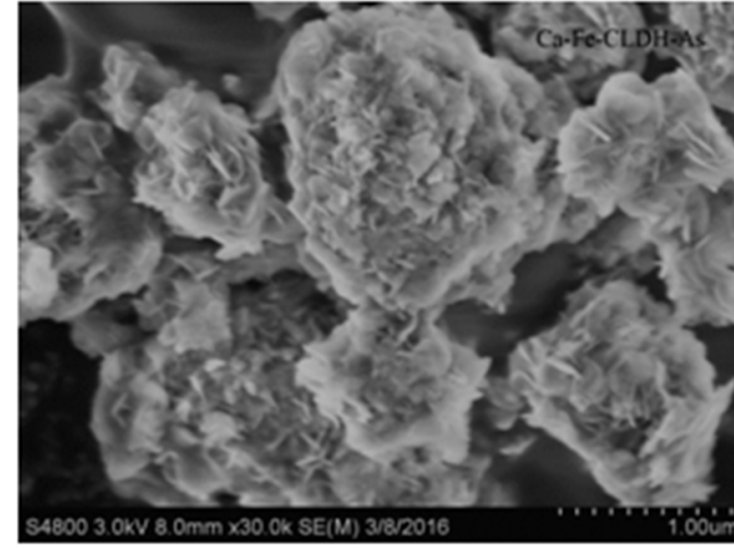

(b)

Figure 7. (a) XRD pattern of CaFe-CLDH after adsorption of arsenate. (b) SEM image pattern of CaFe-CLDH after adsorption arsenate.

\section{Conclusions}

A series of calcium-containing layered double hydroxides were successfully synthesized using a comparative simple synthesis method and were then characterized. The effects of various factors during the adsorption process, such as $\mathrm{pH}$ of the solution, dosage of materials, coexisting ions, contact time, and initial arsenate concentration, were evaluated. The maximum adsorption capacity of arsenate on the three synthesized materials ( $\mathrm{CaFe}-\mathrm{CLDH}, \mathrm{CaFe}-\mathrm{Cl}-\mathrm{LDH}$, and $\mathrm{CaFe}-\mathrm{NO}_{3}-\mathrm{LDH}$ ) were $156.0 \mathrm{mg} \cdot \mathrm{g}^{-1}, 150.5 \mathrm{mg} \cdot \mathrm{g}^{-1}$ and $148.0 \mathrm{mg} \cdot \mathrm{g}^{-1}$, respectively. When the concentration of CaFe-CLDH was $0.5 \mathrm{~g} \cdot \mathrm{L}^{-1}$ the concentration of arsenate was reduced from $5000 \mu \mathrm{g} \cdot \mathrm{L}^{-1}$ to $10 \mu \mathrm{g} \cdot \mathrm{L}^{-1}$ after adsorption. When CaFe-CLDH was applied in the decontamination of arsenic in actual water samples, it can fully meet the requirements for the concentrations of arsenic in drinking water standards of the 
World Health Organization, EPA and China. The synthesized CaFe-CLDH is potentially an effective adsorbent for the removal of arsenic contamination.

Supplementary Materials: The following are available online at http:/ /www.mdpi.com/2073-4441/10/9/1150/s1, Figure S1: SEM images of materials.

Author Contributions: Conceptualization, Z.Z.; Data curation, Y.Q.; Formal analysis, H.Z.; Funding acquisition, H.L. and Z.Z.; Investigation, S.L.; Methodology, H.L. and S.L.; Project administration, J.Z. and Z.Z.; Supervision, Z.Z.; Visualization, H.L.; Writing—original draft, H.L.; Writing—review \& editing, Z.Z.

Funding: This research was funded by the Swedish Research Council (CHEMSTRRES-YRD via the contract Dnr. 639-2013-6913) and the China Postdoctoral Science Foundation (No. 2017M621529).

Acknowledgments: The authors thank the supports from the Swedish Research Council (CHEMSTRRES-YRD via the contract Dnr. 639-2013-6913) and the China Postdoctoral Science Foundation (No. 2017M621529)

Conflicts of Interest: The authors declare no conflict of interest. The funders had no role in the design of the study; in the collection, analyses, or interpretation of data; in the writing of the manuscript, and in the decision to publish the results.

\section{References}

1. Ravenscroft, P.; Brammer, H.; Richards, K. Arsenic Pollution: A Global Synthesis; Wiley-Blackwell: Oxford, UK, 2009; p. 588.

2. Rodriguez-Lado, L.; Sun, G.; Berg, M.; Zhang, Q.; Xue, H.; Zheng, Q.; Johnson, C.A. Groundwater arsenic contamination throughout china. Science 2013, 341, 866-868. [CrossRef] [PubMed]

3. Mandal, B.K.; Suzuki, K.T. Arsenic round the world: A review. Talanta 2002, 58, 201-235. [CrossRef]

4. Alonso, D.L.; Latorre, S.; Castillo, E.; Brandao, P.F.B. Environmental occurrence of arsenic in colombia: A review. Environ. Pollut. 2014, 186, 272-281. [CrossRef] [PubMed]

5. Bundschuh, J.; Litter, M.I.; Parvez, F.; Roman-Ross, G.; Nicolli, H.B.; Jean, J.S.; Liu, C.W.; Lopez, D.; Armienta, M.A.; Guilherme, L.R.G.; et al. One century of arsenic exposure in latinamerica: A review of history and occurrence from 14 countries. Sci. Total Environ. 2012, 429, 2-35. [CrossRef] [PubMed]

6. Liu, J.L.; Yang, T.; Chen, Q.Y.; Liu, F.; Wang, B.B. Distribution and potential ecological risk of heavy metals in the typical eco-units of haihe river basin. Front. Environ. Sci. Eng. 2016, 10, 103-113. [CrossRef]

7. Meng, Z.G.; Korfiatis, G.P.; Christodoulatos, C.; Bang, S. Treatment of arsenic in bangladesh well water using a household co-precipitation and filtration system. Water Res. 2001, 35, 2805-2810. [CrossRef]

8. Śmiech, K.; Tolsma, A.; Kovács, T.; Dalbosco, V.; Yasadi, K.; Groendijk, L.; Agostinho, L. Comparing mixed-media and conventional slow-sand filters for arsenic removal from groundwater. Water 2018, 10, 119. [CrossRef]

9. Rahman, M.A.; Hasegawa, H.; Ueda, K.; Maki, T.; Okumura, C.; Rahman, M.M. Arsenic accumulation in duckweed (Spirodelapolyrhiza L.): A good option for phytoremediation. Chemosphere 2007, 69, 493-499. [CrossRef] [PubMed]

10. Chen, Y.S.; Xu, W.Z.; Shen, H.L.; Yan, H.L.; Xu, W.X.; He, Z.Y.; Ma, M. Engineering arsenic tolerance and hyperaccumulation in plants for phytoremediation by a PvACR3 transgenic approach. Environ. Sci. Technol. 2013, 47, 9355-9362. [CrossRef] [PubMed]

11. Van Genuchten, C.M.; Addy, S.E.A.; Pena, J.; Gadgil, A.J. Removing arsenic from synthetic groundwater with iron electrocoagulation: An Fe and as K-edge EXAFS study. Environ. Sci. Technol. 2012, 46, 986-994. [CrossRef] [PubMed]

12. Sun, Y.K.; Zhou, G.M.; Xiong, X.M.; Guan, X.H.; Li, L.N.; Bao, H.L. Enhanced arsenite removal from water by $\mathrm{Ti}\left(\mathrm{SO}_{4}\right)_{2}$ coagulation. Water Res. 2013, 47, 4340-4348. [CrossRef] [PubMed]

13. Nidheesh, P.V.; Singh, T.S.A. Arsenic removal by electrocoagulation process: Recent trends and removal mechanism. Chemosphere 2017, 181, 418-432. [CrossRef] [PubMed]

14. Sato, Y.; Kang, M.; Kamei, T.; Magara, Y. Performance of nanofiltration for arsenic removal. Water Res. 2002, 36, 3371-3377. [CrossRef]

15. Uddin, M.T.; Mozumder, M.S.I.; Islam, M.A.; Deowan, S.A.; Hoinkis, J. Nanofiltration membrane process for the removal of arsenic from drinking water. Chem. Eng. Technol. 2007, 30, 1248-1254. [CrossRef] 
16. Awual, M.R.; Hossain, M.A.; Shenashen, M.A.; Yaita, T.; Suzuki, S.; Jyo, A. Evaluating of arsenic(V) removal from water by weak-base anion exchange adsorbents. Environ. Sci. Pollut. Res. 2013, 20, 421-430. [CrossRef] [PubMed]

17. Anirudhan, T.S.; Unnithan, M.R. Arsenic(V) removal from aqueous solutions using an anion exchanger derived from coconut coir pith and its recovery. Chemosphere 2007, 66, 60-66. [CrossRef] [PubMed]

18. Qi, P.; Pichler, T. Competitive adsorption of As (III) and As (V) by ferrihydrite: Equilibrium, kinetics, and surface complexation. Water Air Soil Pollut. 2016, 227, 387. [CrossRef]

19. Ma, J.; Guo, H.; Lei, M.; Zhou, X.; Li, F.; Yu, T.; Wei, R.; Zhang, H.; Zhang, X.; Wu, Y. Arsenic adsorption and its fractions on aquifer sediment: Effect of $\mathrm{pH}$, arsenic species, and iron/manganese minerals. Water Air Soil Pollut. 2015, 226, 260. [CrossRef]

20. Usman, M.; Katsoyiannis, I.; Mitrakas, M.; Zouboulis, A.; Ernst, M. Performance evaluation of small sized powdered ferric hydroxide as arsenic adsorbent. Water 2018, 10, 957. [CrossRef]

21. Singh, R.; Singh, S.; Parihar, P.; Singh, V.P.; Prasad, S.M. Arsenic contamination, consequences and remediation techniques: A review. Ecotoxicol. Environ. Saf. 2015, 112, 247-270. [CrossRef] [PubMed]

22. Sarkar, A.; Paul, B. The global menace of arsenic and its conventional remediation-A critical review. Chemosphere 2016, 158, 37-49. [CrossRef] [PubMed]

23. Goh, K.-H.; Lim, T.-T.; Dong, Z. Application of layered double hydroxides for removal of oxyanions: A review. Water Res. 2008, 42, 1343-1368. [CrossRef] [PubMed]

24. Cavani, F.; Trifirò, F.; Vaccari, A. Hydrotalcite-type anionic clays: Preparation, properties and applications. Catal. Today 1991, 11, 173-301. [CrossRef]

25. Zubair, M.; Daud, M.; McKay, G.; Shehzad, F.; Al-Harthi, M.A. Recent progress in layered double hydroxides (LDH)-containing hybrids as adsorbents for water remediation. Appl. Clay Sci. 2017, 143, 279-292. [CrossRef]

26. Asiabi, H.; Yamini, Y.; Shamsayei, M. Highly selective and efficient removal of arsenic(V), chromium(VI) and selenium(VI) oxyanions by layered double hydroxide intercalated with zwitterionic glycine. J. Hazard. Mater. 2017, 339, 239-247. [CrossRef] [PubMed]

27. Kang, D.J.; Yu, X.L.; Tong, S.R.; Ge, M.F.; Zuo, J.C.; Cao, C.Y.; Song, W.G. Performance and mechanism of $\mathrm{Mg} / \mathrm{Fe}$ layered double hydroxides for fluoride and arsenate removal from aqueous solution. Chem. Eng. J. 2013, 228, 731-740. [CrossRef]

28. Al-Jaberi, M.; Naille, S.; Dossot, M.; Ruby, C. Inter layer interaction in Ca-Fe layered double hydroxides intercalated with nitrate and chloride species. J. Mol. Struct. 2015, 1102, 253-260. [CrossRef]

29. Sipiczki, M.; Srankó, D.F.; Kukovecz, Á.; Kónya, Z.; Sipos, P.; Pálinkó, I. Synthesis and characterisation of alkaline earth-iron(III) double hydroxides. Chem. Pap. 2011, 65, 840-846. [CrossRef]

30. Ferencz, Z.; Szabados, M.; Varga, G.; Csendes, Z.; Kukovecz, A.; Konya, Z.; Carlson, S.; Sipos, P.; Palinko, I. Mechanochemical synthesis and intercalation of $\mathrm{Ca}(\mathrm{II}) \mathrm{Fe}(\mathrm{III})-$ layered double hydroxides. J. Solid State Chem. 2016, 233, 236-243. [CrossRef]

31. Sun, Z.; Park, J.-S.; Kim, D.; Shin, C.-H.; Zhang, W.; Wang, R.; Rao, P. Synthesis and adsorption properties of ca-al layered double hydroxides for the removal of aqueous fluoride. Water Air Soil Pollut. 2017, $228,23$. [CrossRef]

32. Abdellattif, M.; Mokhtar, M. MgAl-layered double hydroxide solid base catalysts for henry reaction: A green protocol. Catalysts 2018, 8, 133. [CrossRef]

33. Sipiczki, M.; Kuzmann, E.; Homonnay, Z.; Megyeri, J.; Palinko, I.; Sipos, P. The structure and stability of cafe layered double hydroxides with various Ca:Fe ratios studied by mossbauer spectroscopy, X-ray diffractometry and microscopic analysis. J. Mol. Struct. 2013, 1044, 116-120. [CrossRef]

34. Gong, Z.; Lu, X.; Ma, M.; Watt, C.; Le, X.C. Arsenic speciation analysis. Talanta 2002, 58, 77-96. [CrossRef]

35. Rahman, M.T.; Kameda, T.; Kumagai, S.; Yoshioka, T. Adsorption isotherms and kinetics of arsenic removal from aqueous solution by mg-al layered double hydroxide intercalated with nitrate ions. React. Kinet. Mech. Catal. 2017, 120, 703-714. [CrossRef]

36. Ma, L.J.; Islam, S.M.; Liu, H.Y.; Zhao, J.; Sun, G.B.; Li, H.F.; Ma, S.L.; Kanatzidis, M.G. Selective and efficient removal of toxic oxoanions of As (III), As (V), and $\mathrm{Cr}$ (VI) by layered double hydroxide intercalated with $\mathrm{MoS}_{4}{ }^{2-}$. Chem. Mater. 2017, 29, 3274-3284. [CrossRef]

37. Miller, F.A.; Wilkins, C.H. Infrared spectra and characteristic frequencies of inorganic ions. Anal. Chem. 1952, 24, 1253-1294. [CrossRef] 
38. Nakamoto, K. Infrared and raman spectra of inorganic and coordination compounds. In Handbook of Vibrational Spectroscopy; John Wiley \& Sons, Ltd.: London, UK, 2006.

39. Balbuena, P.B.; Gubbins, K.E. Classification of adsorption behavior: Simple fluids in pores of slit-shaped geometry. Fluid Phase Equilib. 1992, 76, 21-35. [CrossRef]

40. Carja, G.; Nakamura, R.; Aida, T.; Niiyama, H. Textural properties of layered double hydroxides: Effect of magnesium substitution by copper or iron. Microporous Mesoporous Mater. 2001, 47, 275-284. [CrossRef]

41. Guo, Y.W.; Zhu, Z.L.; Qiu, Y.L.; Zhao, J.F. Adsorption of arsenate on Cu/Mg/Fe/La layered double hydroxide from aqueous solutions. J. Hazard. Mater. 2012, 239, 279-288. [CrossRef] [PubMed]

42. Langmuir, I. The constitution and fundamental properties of solids and liquids. II. Liquids. J. Am. Chem. Soc. 1917, 39, 1848-1906. [CrossRef]

43. Freundlich, H. Colloid and Capillary Chemistry; Methuen: London, UK, 1926.

44. Zhang, S.; Niu, H.; Cai, Y.; Zhao, X.; Shi, Y. Arsenite and arsenate adsorption on coprecipitated bimetal oxide magnetic nanomaterials: $\mathrm{MnFe}_{2} \mathrm{O}_{4}$ and $\mathrm{CoFe}_{2} \mathrm{O}_{4}$. Chem. Eng. J. 2010, 158, 599-607. [CrossRef]

45. Chammui, Y.; Sooksamiti, P.; Naksata, W.; Thiansem, S.; Arqueropanyo, O.A. Removal of arsenic from aqueous solution by adsorption on leonardite. Chem. Eng. J. 2014, 240, 202-210. [CrossRef]

46. Turk, T. Removal of dissolved arsenic by pyrite Ash waste. Mine Water Environ. 2017, 36, 255-263. [CrossRef]

47. Chen, W.F.; Parette, R.; Zou, J.Y.; Cannon, F.S.; Dempsey, B.A. Arsenic removal by iron-modified activated carbon. Water Res. 2007, 41, 1851-1858. [CrossRef] [PubMed]

48. Xu, W.H.; Wang, J.; Wang, L.; Sheng, G.P.; Liu, J.H.; Yu, H.Q.; Huang, X.J. Enhanced arsenic removal from water by hierarchically porous $\mathrm{CeO}_{2}-\mathrm{ZrO}_{2}$ nanospheres: Role of surface- and structure-dependent properties. J. Hazard. Mater. 2013, 260, 498-507. [CrossRef] [PubMed]

49. Violante, A.; Pucci, M.; Cozzolino, V.; Zhu, J.; Pigna, M. Sorption/desorption of arsenate on/from Mg-Al layered double hydroxides: Influence of phosphate. J. Colloid Interface Sci. 2009, 333, 63-70. [CrossRef] [PubMed]

50. Ardau, C.; Frau, F.; Lattanzi, P. New data on arsenic sorption properties of Zn-Al sulphate layered double hydroxides: Influence of competition with other anions. Appl. Clay Sci. 2013, 80-81, 1-9. [CrossRef]

51. Ho, Y.S.; McKay, G. The kinetics of sorption of divalent metal ions onto sphagnum moss peat. Water Res. 2000, 34, 735-742. [CrossRef]

52. Bektas, N.; Aydin, S.; Oncel, M.S. The adsorption of arsenic ions using beidellite, zeolite, and sepiolite clays: A study of kinetic, equilibrium and thermodynamics. Sep. Sci. Technol. 2011, 46, 1005-1016. [CrossRef]

53. Taty-Costodes, V.C.; Fauduet, H.; Porte, C.; Delacroix, A. Removal of $\mathrm{Cd}(\mathrm{II})$ and $\mathrm{Pb}(\mathrm{II})$ ions, from aqueous solutions, by adsorption onto sawdust of Pinussylvestris. J. Hazard. Mater. 2003, 105, 121-142. [CrossRef] [PubMed]

54. Giménez, J.; Martínez, M.; de Pablo, J.; Rovira, M.; Duro, L. Arsenic sorption onto natural hematite, magnetite, and goethite. J. Hazard. Mater. 2007, 141, 575-580. [CrossRef] [PubMed]

55. Raven, K.P.; Jain, A.; Loeppert, R.H. Arsenite and arsenate adsorption on ferrihydrite: Kinetics, equilibrium, and adsorption envelopes. Environ. Sci. Technol. 1998, 32, 344-349. [CrossRef]

56. Chetia, M.; Goswamee, R.L.; Banerjee, S.; Chatterjee, S.; Singh, L.; Srivastava, R.B.; Sarma, H.P. Arsenic removal from water using calcined Mg-Al layered double hydroxide. Clean Technol. Environ. Policy 2012, 14, 21-27. [CrossRef]

57. Yoshida, M.; Koilraj, P.; Qiu, X.; Hirajima, T.; Sasaki, K. Sorption of arsenate on MgAl and MgFe layered double hydroxides derived from calcined dolomite. J. Environ. Chem. Eng. 2015, 3, 1614-1621. [CrossRef]

(C) 2018 by the authors. Licensee MDPI, Basel, Switzerland. This article is an open access article distributed under the terms and conditions of the Creative Commons Attribution (CC BY) license (http://creativecommons.org/licenses/by/4.0/). 